\title{
Understanding key engineering changes for materials management in ETO environment
}

\author{
Pavan K Sriram ${ }^{1}$, Heidi C Dreyer ${ }^{1}$, and Erlend Alfnes ${ }^{1}$ \\ ${ }^{1}$ Norwegian University of Science and Technology, Trondheim, Norway \\ pavan.sriramentnu.no, heidi.c.dreyerentnu.no, \\ erlend.alfnesantnu.no
}

\begin{abstract}
Researchers have recognized engineering changes affecting operations as a major obstacle to the delivery of the product in ETO environment. However, there is little academic literature addressing sources of engineering changes that affect materials management throughout the order fulfillment process in an ETO environment. The key research question addressed in this paper is how the substantive sources of engineering changes impact materials in ETO environment can be identified and categorized. Due to the nature of different supply chain configurations different engineering change situations exists within and across these companies.
\end{abstract}

Keywords: engineering changes, engineer-to-order, case studies, materials management

\section{Introduction}

Companies that operate in ETO strategy build unique products designed to customer specifications. Products are complex with long lead times and the customer is heavily involved throughout the entire design and manufacturing process (Gosling and Naim, 2009). In these companies, engineering changes are way of life due to high probability of design and production changes (Tavčar and Duhovnik, 2005). Moreover, because materials account for 50-60 percent of total project costs, its effective management provides an opportunity to increase cost competitiveness, market share and profitability (Wänström and Jonsson, 2006). Materials management includes all activities and processes which aim to address material choice, lot sizes (for purchased or produced materials or parts), delivery location (to inventory, to shop floor, or directly to customer location) and time (to purchase or initiate production) (Wänström and Jonsson, 2006). Within the context of an ETO company, materials management usually involves strategy, planning and control of materials and information influencing the flow of materials. If the engineering changes (EC) are not recorded and monitored, then it would be hard to determine who bears the responsibility of the additional cost and it may act as a critical factor affecting the materials management while impacting the profitability for ETO manufacturers. Despite of their significant impact on the ETO manufacturing environment, it is actually not too surprising to see the lack of research

adfa, p. 1, 2011.

(c) Springer-Verlag Berlin Heidelberg 2011 
done in ECs within the context of materials management under engineering change situations in ETO environment. In this paper we present an overall understating of the key engineering changes that affect the materials management ETO environment. The aim is to provide a categorization framework to understand the developments that have emerged in the literature as well highlight its applicability in the industry.

\section{Literature Review}

Material planning in ETO production environment has historically been challenging (Hendry and Kingsman, 1989, Hicks et al., 2007, Jin and Thomson, 2003). Following the industrial revolution and the increasing sophistication of industrial equipment and product complexity increased with the high cost implications. One can imagine the material planning challenge faced when the first commercial aero plane was built or the challenge of building a subsea compression station for a field development project operated by a multinational corporation.

\subsection{Engineering change management}

Engineering change is concerned with changes/alterations in a product and the engineering change management is the process which describes and controls the change process (Kocar and Akgunduz, 2010).

1. Definition engineering change: We used (Jarratt et al., 2011) comprehensive definition, "An engineering change is an alteration made to parts, drawings or software that have already been released during the product design process. The change can be any size or type; the change can involve any number of people and take any length of time".

2. Classification of engineering changes: The ECs were classified in accordance with their impact on the company, on time; and based on urgency (Jarratt et al., 2011). (Huang and Mak, 1999) developed an EC taxonomy based on the following categories: routine, expedite, emergency, high risk and mandatory.

\subsection{Engineering changes and its impact on materials management}

In ETO companies due to the degree of complexity, innovation and variability of the product, an ECM system should consider the degree of unpredictability, and also have capability to manage a good cooperation with external suppliers and customers approvals etc. (Tavčar and Duhovnik, 2005). As in the other companies the change in ETO companies can range from a small change in single component to major ones, which might have a knock-on effect on the entire product (Jarratt et al., 2011). Hence, effective, reliable, and robust ECM system is required to manage exceptional cases.

Factors effecting Engineering change: Based on the literature review and analysis, six categories of challenges have been identified within the ECM. However, two of the 
challenges (e, f) will not be emphasized as it is mainly considered as organizational issue, with no ECM related solution.

a. Unidentified change propagation: Possessing the capabilities to identify change propagation has been recognized as an important and critical skill in the ECM process (Giffin et al., 2009) Change propagation stems from components being coupled with each other, either directly or indirectly (Eckert et al., 2004). Complex products often experiences more change propagation than other products, due to more couplings (Cheng and Carrillo, 2012). Other major problem that ECM need's to take into account is the engineering bills of materials (EBOM) needs to be transformed to manufacturing bills of material (MBOM), but MBOM transformation has to be done in such a way that it fit the particularities of each manufacturing sites. Also the ECM system should be having flexibility to interact with the BOM conversion module as its one of the most important challenge that needs to be addressed.

$b$. Knowledge Management: For new product development, knowledge management is considered to be critical (Lee and Lee, 2005, Lee et al., 2006). Changes are more likely to propagate due to the innovation factor. This is due to low degree of knowledge and information (Jarratt et al., 2011). The ECM system today does not possess the capabilities to easily capture and manage knowledge that is generated from collaboration and the decision making process ((Lee et al., 2006). Hence, the knowledgebase available to decision makers is significantly reduced, and decisions will rely more heavily on personal experience.

c. Distributed environment: As stated, the ECM process is a rather complex process, involving different disciplines both internally (e.g. production-supply), externally (e.g. design collaboration between multiple companies) (Terwiesch and Loch, 1999). Companies tend to work in a decentralized manner, even within the internal departments (Koçoğlu et al., 2011). This is mainly addressed towards management group/staff. The review and approval process in ETO environment is difficult and time-consuming, even for technical staff. Thus, the management might have difficulties comprehending complicated parametrical and graphical information correctly, something that could lead to misinterpretations and errors, further delaying the EC process capacity.

$d$. Capacity and congestion: The problem of capacity and congestion has been defined as a general problem in this project. Although it might have an impact on the actual ECR lead time, as discussed by (Terwiesch and Loch, 1999), it appears more as a project structure issue than an ECM issue. (Terwiesch and Loch, 1999)argues that one of the reasons for long ECR lead time is due to the limited capacity of an individual engineer. In the Case "The climate control system in automobile development" written by (Terwiesch and Loch, 1999)about 50\% of this capacity was consumed by the current development project. The second general problem, also identified by (Terwiesch and Loch, 1999) was setups and batching. Batching is an old and familiar principle in management research, and its advantages in the presence of fixed setup costs or setup delays are unquestionable. However, batching also has its downsides; one of them stemming from the time a task has to wait for its cohorts in the same batch, to proceed. Applying this to ECM, results in ECs not being implemented directly on occurrence, but rather 
batched with other changes, lengthening the EC lead time, and possibly causing congestion problems as discussed above.

\subsection{Current strategies and methods to cope with for materials management under Engineering change situations}

Strategies have been proposed in literature to meet these needs or manage these challenges. It is more common in ETO to find companies using order-based management for unique components/materials demand and the reorder point for more standardized components. Indeed, this leads to the need to have a differentiated strategy similar to that proposed by (Semini et al., 2014). Moreover, many manufacturing companies often have more than one material planning method. This was highlighted by (Jonsson and Mattsson, 2003) in a study of companies in the food manufacturing and chemicals, mechanical engineering (which made up almost half of the companies sampled). ). The findings are summarized in the table which follows.

Table 1. Proposed solutions to material planning challenges under engineering changes (from literature)

\begin{tabular}{|c|c|}
\hline Author (year) & Proposed solutions to characteristics/ challenges \\
\hline $\begin{array}{l}\text { (Harhalakis and Yang, } \\
\text { 1988) }\end{array}$ & $\begin{array}{l}\text { - An integration of MRP with CPM where the schedules are determined by the } \\
\text { CPM and the MRP module computes the firmed dates for each activity after } \\
\text { interacting with inventory records and open/planned order records [Limitation: } \\
\text { the integration in now 'organic', and many tasks must still be carried out in a } \\
\text { parallel system and the data fed into the MRP system] }\end{array}$ \\
\hline ((Silver et al., 1998) & $\begin{array}{l}\text { - Include an experienced materials management person in the early phase (con- } \\
\text { cept and feasibility) } \\
\text { - Closer collaboration between engineering and materials } \\
\text { - Develop mechanisms for handling design changes } \\
\text { - Have backup supplier for every commodity to guarantee supply } \\
\text { - Reduce the need for expediting by developing 'responsible' suppliers/vendors } \\
\text { - Implement warehouse material control and feedback mechanism such tagging }\end{array}$ \\
\hline $\begin{array}{l}\text { (Jonsson } \\
\text { Mattsson, 2003) }\end{array}$ & $\begin{array}{l}\text { - Both MRP and order-based planning are used in complex customer pro- } \\
\text { duction environments. However, order based planning is most suited for both } \\
\text { MTO and ETO type production environments }\end{array}$ \\
\hline $\begin{array}{l}\text { (Stevenson * et al., } \\
2005)\end{array}$ & - Workload control is the most appropriate PPC approach for MTO companies \\
\hline (Song et al., 2006) & $\begin{array}{l}\text { - Manage (find optimum) raw material release times to minimize the work-in- } \\
\text { progress holding cost, product earliness cost, and product tardiness cost }\end{array}$ \\
\hline $\begin{array}{l}\text { (Wänström } \\
\text { Jonsson, 2006) }\end{array}$ & $\begin{array}{l}\text { - Date effective; Blocking change; Serial number; Firm planned orders; Use-up } \\
\text { technique } \\
\text { - Use a self-correcting (which will not place replenishment orders when there } \\
\text { are no customer orders or backlogs to be fulfilled) re-order point system }\end{array}$ \\
\hline
\end{tabular}




\section{Categorization of engineering changes}

(Wänström and Jonsson, 2006) categorized the characteristics as engineering change, demand, material supply, manufacturing, and product. Engineering change (EC) characteristics comprise attributes such as urgency grade, dependency of engineering changes or the degree of interconnectedness of the change requests and activities and information quality. Demand characteristics include demand volume, demand lumpiness for either products or component items, uncertainty, demand time distribution for planning purposes, type of demand, P/D ratio, customer service elements and ramp-up level. Product characteristics comprise BOM complexity indicated by the depth and width of the BOM structure (Song et al., 2006, Hicks et al., 2007), product/item value, customer specific items and degree of benefit. Manufacturing process characteristics comprise shop floor layout, throughput time, batch size, inventory recording, material addresses, volume flexibility, product mix flexibility, delivery flexibility, use of new tools for engineering change and manufacturing scrap. Supplier characteristics comprise supplier service elements (such as agreements on delivery precision and who bears the cost of supplier scrap), material supply scrap in the company of interest, lot size (whether to calculate or use any order cost optimization technique, or the preference of full trucks or pallets to minimize transport costs) and the type of procurement ordering (are purchase orders sent once per day or when there is a customer order). The findings are summarized in Table 2.

Table 2. Categorization of engineering change situations affecting materials management from literature in an ETO environment

\begin{tabular}{|c|c|c|}
\hline Categories & Complicating factors & References \\
\hline $\begin{array}{l}\text { Products at- } \\
\text { tribute charac- } \\
\text { teristics }\end{array}$ & $\begin{array}{l}\text { Deep and complex product structure Complex- } \\
\text { ity of design and engineering } \\
\text { Uncertainty (and changes) of product specifica- } \\
\text { tion } \\
\text { High degree of customer specification (customi- } \\
\text { zation and variants) } \\
\text { Critical parts dictated by project production 'crit- } \\
\text { ical path' }\end{array}$ & $\begin{array}{l}\text { (Gelders, 1991); (Jonsson and } \\
\text { Mattsson, 2003, Jin and } \\
\text { Thomson, 2003);(Krishnamurthy } \\
\text { and Suri, 2009);(Jonsson and } \\
\text { Mattsson, 2008) }\end{array}$ \\
\hline $\begin{array}{l}\text { Manufacturing } \\
\text { process char- } \\
\text { acteristics }\end{array}$ & $\begin{array}{l}\text { High product mix and low volume } \\
\text { process characteristics } \\
\text { Dynamic nature necessitates frequent replanning } \\
\text { and } \\
\text { 'nervousness' } \\
\text { Complications of concurrent activities Complex- } \\
\text { ity of process routings Complication of multi-pro- } \\
\text { ject planning } \\
\text { Engineering activities takes a large part of the or- } \\
\text { der- to-delivery process } \\
\text { Functional or job-shop type of flow configuration }\end{array}$ & $\begin{array}{l}\text { (Barrett and LaForge, } \\
\text { 1991);(Yeung et al., 1998);(Hicks } \\
\text { et al., 2007, Jin and Thomson, } \\
\text { 2003) }\end{array}$ \\
\hline
\end{tabular}




\begin{tabular}{|c|c|c|}
\hline $\begin{array}{l}\text { Market de- } \\
\text { mand charac- } \\
\text { teristics }\end{array}$ & $\begin{array}{l}\text { Uncertain time and quantity of customer order } \\
\text { High service level requirements } \\
\text { Need for quick response to seize market opportu- } \\
\text { nities } \\
\text { Uncertainty of due date setting and cost estima- } \\
\text { tion } \\
\text { Few large customer orders per year }\end{array}$ & $\begin{array}{l}\text { (Bertrand and Muntslag, 1993, } \\
\text { Hendry and Kingsman, 1989, } \\
\text { Abd Rahman Abdul and Mohd } \\
\text { Shariff Nabi, 2003) }\end{array}$ \\
\hline $\begin{array}{l}\text { Supply charac- } \\
\text { teristics }\end{array}$ & $\begin{array}{l}\text { Risk of supplier competition } \\
\text { Complication of supplier relationship (number, } \\
\text { capacity reservations, contracts) } \\
\text { Difficulty in knowing the actual material con- } \\
\text { sumption during production period }\end{array}$ & $\begin{array}{l}\text { (Jonsson and Mattsson, } 2003 \text {, } \\
\text { Tyagi et al., 2013) }\end{array}$ \\
\hline $\begin{array}{l}\text { Engineering } \\
\text { change }(\mathbf{E C}) \\
\text { characteristics }\end{array}$ & $\begin{array}{l}\text { Customer involvement in the product specifica- } \\
\text { tion close to the time the product is near com- } \\
\text { pleted Panic towards the end of the project }\end{array}$ & $\begin{array}{l}\text { (Silver et al., 1998, Wänström } \\
\text { and Jonsson, 2006, Jarratt et al., } \\
\text { 2011) }\end{array}$ \\
\hline
\end{tabular}

\section{Conclusion}

The capability of managing ECs efficiently is thus a major advantage due to ECs potentially big impacts. Thus, it does not come as a surprise that this study reveals that efficient materials management under engineering change situation. The literature review on engineering change identified four core problems, change propagation, knowledge management, collaboration, and decision makers. Furthermore, by using these four problems as a basis, we developed a conceptual framework, which may ease and be used for developing engineering change management systems to effectively handle and allocate materials. The framework is an attempt to response to the inadequate attention to materials management under engineering change in both research and industry, and is believed to assist in bringing more attention to the current materials management issues in the industry.

\section{Acknowledgment}

This research has been carried out as part of the EFFEKT, LIFT and SUSPRO research project being carried out at NTNU. The authors thank the partners in the project for facilitating this research work.

\section{$5 \quad$ References}

1. Abd Rahman Abdul, R. \& Mohd Shariff Nabi, B. 2003. The need for a new product development framework for engineer-to-order products. European Journal of Innovation Management, 6, 182-196.

2. Barrett, R. T. \& LaForge, R. L. 1991. A study of replanning frequencies in a material requirements planning system. Computers \& operations research, 18, 569-578. 
3. Bertrand, J. W. M. \& Muntslag, D. R. 1993. Production control in engineer-to-order firms. International Journal of Production Economics, 30-31, 3-22.

4. Cheng, L. C. V. \& Carrillo, E. E. 2012. Assessing supplier performances under partnership in project-type procurement. Industrial Management and Data Systems, 112, 290-312.

5. Eckert, C., Clarkson, P. J. \& Zanker, W. 2004. Change and customisation in complex engineering domains. Research in Engineering Design, 15, 1-21.

Gelders, L. F. 1991. Production control in an 'engineer-to-order' environment. Production Planning \& Control, 2, 280-285.

6. Giffin, M., De Weck, O., Bounova, G., Keller, R., Eckert, C. \& Clarkson, P. J. 2009. Change propagation analysis in complex technical systems. Journal of Mechanical Design, 131, 081001.

7. Gosling, J. \& Naim, M. M. 2009. Engineer-to-order supply chain management: A literature review and research agenda. International Journal of Production Economics, 122, 741-754.

8. Harhalakis, G. \& Yang, S. S. 1988. Integration of network analysis systems with MRP in a make-to-order manufacturing environment. Engineering Costs and Production Economics, 14, 47-59.

9. Hendry, L. C. \& Kingsman, B. G. 1989. Production planning systems and their applicability to make-to-order companies. European Journal of Operational Research, 40, 1-15.

10. Hicks, C., Song, D. P. \& Earl, C. F. 2007. Dynamic scheduling for complex engineer-to-order products. International Journal of Production Research, 45, 34773503 .

11. Huang, G. \& Mak, K. 1999. Web-based collaborative conceptual design. Journal of Engineering Design, 10, 183-194.

Jarratt, T. A. W., Eckert, C., Caldwell, N. H. M. \& Clarkson, P. 2011. Engineering change: an overview and perspective on the literature. Research in Engineering Design, $1-22$.

12. Jin, G. \& Thomson, V. 2003. A new framework for MRP systems to be effective in engineered-to-order environments. Robotics and Computer-Integrated Manufacturing, 19, 533-541.

13. Jonsson, P. \& Mattsson, S.-A. 2008. Inventory management practices and their implications on perceived planning performance. International Journal of Production Research, 46, 1787 - 1812.

14. Jonsson, P. \& Mattsson, S. A. 2003. The implications of fit between planning environments and manufacturing planning and control methods. International Journal of Operations \& Production Management, 23, 872-900.

15. Kocar, V. \& Akgunduz, A. 2010. ADVICE: A virtual environment for Engineering Change Management. Computers in Industry, 61, 15-28.

16. Koçoğlu, İ., İmamoğlu, S. Z., İnce, H. \& Keskin, H. 2011. The effect of supply chain integration on information sharing:Enhancing the supply chain performance. Procedia - Social and Behavioral Sciences, 24, 1630-1649. 
17. Krishnamurthy, A. \& Suri, R. 2009. Planning and implementing POLCA: a cardbased control system for high variety or custom engineered products. Production planning and control, 20, 596-610.

18. Lee, H. J., Ahn, H. J., Kim, J. W. \& Park, S. J. 2006. Capturing and reusing knowledge in engineering change management: A case of automobile development. Information Systems Frontiers, 8, 375-394.

19. Lee, H. J. \& Lee, J. K. 2005. An effective customization procedure with configurable standard models. Decision Support Systems, 41, 262-278.

20. Semini, M., Haartveit, D. G., Alfnes, E., Arica, E., Brett, P. O. \& Strandhagen, J. O. 2014. Strategies for customized shipbuilding with different customer order decoupling points. Proc IMechE, Part M: J Engineering for the Maritime Environment, In press.

21. Silver, E. A., Pyke, D. F. \& Peterson, R. 1998. Inventory Management and Production Planning and Scheduling, New York, John Wiley \& Sons.

22. Song, D. P., Hicks, C. \& Earl, C. F. 2006. An ordinal optimization based evolution strategy to schedule complex make-to-order products. International Journal of Production Research, 44, 4877-4895.

23. Stevenson *, M., Hendry, L. C. \& Kingsman †, B. G. 2005. A review of production planning and control: the applicability of key concepts to the make-to-order industry. International Journal of Production Research, 43, 869-898.

24. Tavčar, J. \& Duhovnik, J. 2005. Engineering change management in individual and mass production. Robotics and Computer-Integrated Manufacturing, 21, 205-215.

25. Terwiesch, C. \& Loch, C. H. 1999. Managing the process of engineering change orders: the case of the climate control system in automobile development. Journal of Product Innovation Management, 16, 160-172.

26. Tyagi, V., Jain, A. \& Jain, P. K. 2013. Towards Integrated Manufacturing Planning and Control: A Review and Classification. IUP Journal of Operations Management, 12, 57-79.

27. Wänström, C. \& Jonsson, P. 2006. The impact of engineering changes on materials planning. Journal of Manufacturing Technology Management, 17, 561-584.

28. Yeung, J., Wong, W. \& Ma, L. 1998. Parameters affecting the effectiveness of MRP systems: a review. International journal of production research, 36, 313-332. 